\title{
Morphophysiological Traits as Indicators of Genetic Diversity in Brazilian Populations of Jatropha curcas L. Grown Under Water Deficit
}

\author{
Leandro Dias da Silva (corresponding author), \\ State University of Southwest Bahia, Department of Crop and Animal Science, Vitória da \\ Conquista, BA, 45031-900, Brazil. E-mail: leodias5@yahoo.com.br
}

\section{Fábio Pinto Gomes}

State University of Santa Cruz, Department of Biological Sciences, Ilhéus, BA, 45662-900,

Brazil. E-mail: gomes@uesc.br

\begin{abstract}
Mateus Pires Barbosa, Raul Antônio Araújo do Bonfim, Mikaela Oliveira Souza, Paulo Araquém Ramos Cairo

State University of Southwest Bahia, Department of Crop and Animal Science, Vitória da Conquista, BA, 45031-900, Brazil
\end{abstract}

Received: Mar. 18, 2020

Accepted: Apr. 19, 2020

Published: Apr. 22, 2020

doi:10.5296/jas.v8i3.16707

URL: https://doi.org/10.5296/jas.v8i3.16707

\begin{abstract}
Jatropha curcas L. (Euphorbiaceae) is a species grown in tropicalcountries and used for biodiesel production. Morphophysiological traits were analyzed to assess the genetic diversity in nine genotypes of $J$. curcas under deficit water. Seeds of plants from different populations, collected in diferente brazilian regions, were grown under two water regimes (100\% and 50\% tank capacity). Multivariate analysis was used to characterize genetic diversity. The UPGMA dendrogram built from the genetic distance group indicated the segregation of genotypes into five groups for growth traits and six groups for physiological traits. Then, an principal components analysis was carried out, to evaluate the pattern of character variations and then segregate the characteristics that could distinguish parental genotypes for use in plant breeding. Results showed $65.50 \%$ and $56.02 \%$ for the two first principal components of growth and physiological traits, respectively. Total root area was the most determining trait for genetic dissimilarity (18.9\%) and group formation, followed by
\end{abstract}


plant height (17.9\%) and number of leaves (17.6\%). On the other hand, stomatal conductance (gs) (24.9\%) and guaiacol peroxidase (GPX) (20.9\%) were the most determining physiological traits. The analysis of morphophysiological traits indicated CNPAE-298 and 299 as the most distant genotypes among the plant groups. Under water-limited conditions, total root area, plant height, $g s$ and GPX were the most efficient traits to explain genetic dissimilarity among the genotypes, and for this reason they should be referred as a priority for further studies on genotypes selection in this species.

Keywords: biodiesel, cluster analysis, multivariate, physic nut, principal component analysis

\section{Introduction}

The increase in greenhouse gases concentration in the Earth's atmosphere, notably carbon dioxide $\left(\mathrm{CO}_{2}\right)$, has stimulated the search for renewable fuels, such as biodiesel, in order to reduce fossil fuels consumption. The search for an alternative energy to fossil fuels requires the assessment of renewable and low impact sources on natural environment (Matos et al., 2012). Recently, special attention has been given to the use of biofuel, which causes less environmental problems. Dias et al. (2009) highlight that this new source of energy can be explored by most countries around the world, especially by those from the intertropical range, with Brazil offering the greatest opportunities in this sector. However, the crops used for biofuels production are predominantly food crops (Pimentel and Burgess, 2014), which can have a major negative impact because it promotes food shortages, especially in developing countries. Therefore, it is convenient that species of non-food oleaginous plants should be chosen primarily as a raw material for biofuels production. Among these species, Jatropha curcas L. has great potential for biodiesel production, due to its seeds with oil content in 30-35\% (Basha et al., 2009), in addition to being a species that grows in areas of low rainfall (Maes et al., 2009) and does not compete with food crops (Pompelli et al., 2011).

To become viable, J. curcas cultivation still depends on improvements in technological resources, so that high yields can be obtained in different regions of Brazil (Freitas et al., 2011; Laviola et al., 2012). Its physiological traits, together with its economic potential, can make this species an alternative plant for the production of biofuels in arid and semi-arid regions (Pompelli et al., 2011). In addition, J. curcas has a succulent stem, which acts as a water reserve, which allows to compensate for fluctuations in leaf water content (Maes et al. 2009; Kai and Ming, 2011), providing better drought tolerance. Despite this species is assumed to be drought tolerant, recent reports have shown negative effects of water deficit on several morphophysiological traits (Santana et al., 2015; Oliveira et al., 2016; Silva et al., 2016; Santana et al., 2017; Silva et al., 2019).

The potential of $J$. curcas for biodiesel production has not yet been fully explored, mainly due to its variable and unpredictable yield, which limits its cultivation on a large scale. This limitation can be mitigated by genetic improvement, but for this it is necessary to characterize the existing germplasm, in order to make breeding programs more efficient (Mastan et al., 2012; King et al., 2015).

Genetic variability is fundamental to evolution, without it there could be no selection or adaptation of species to environmental changes (Flood et al., 2011). However, research 
related to the responses of genotypes from different climatic and geographical regions to water deficiency are still considered incipient, requiring better genotypes characterization (Laviola et al., 2014).

Knowledge about the genetic diversity of $J$. curcas at different levels (molecular, morphological, physiological and productive) is essential, since the characterization of germplasm is a basic requirement for the selection of genotypes for extensive planting (Basha and Sujatha, 2007). In addition, commercial plantations require genotypes resulting from the combination of several desirable traits, such as high productivity and traits related to the plant's physiology, mainly tolerance to environmental stresses (Sunil et al., 2013). Studies on growth, yield and quality of $J$. curcas have shown significant genetic differences among genotypes collected in different climatic zones (Rao et al., 2008; Das et al., 2010; Gairola et al., 2011; Srivastava et al., 2011 ; Wani et al., 2012; Singh et al., 2013; Tripathi et al., 2013; Kumar and Singh, 2014). In adittion, assessments on genetic diversity in genotypes of $J$. curcas have been carried out using morphological markers (Montes Osorio et al., 2014; Pazeto et al., 2015). Nevertheless, significant differences were found in seed traits, growth parameters, female / male ratio, and seed production (Rao et al., 2008).

Therefore, knowledge about genetic variability is imperative for the success of breeding programs, thus allowing an efficient selection of different genotypes to produce hybrids and similar genotypes (Pecina-Quintero et al., 2014). Despite this, information in the literature on the characterization of germplasm of $J$. curcas, assessments of different genotypes from various locations, and development of varieties with better agronomic performance is still scarce (King et al., 2009).

Given the great potential of J. curcas for biodiesel production, the characterization of its germplasm is essential both for its domestication and for obtaining high quality genotypes, aiming at its future use in breeding programs. In this context, the present study aimed to evaluate the genetic diversity in Brazilian genotypes of $J$. curcas using morphophysiological traits, and multivariate and principal component analyzes, in order to allow a more divergent and superior genotypes selection.

\section{Materials and Methods}

\subsection{Plant Material and Growth Conditions}

The experiment was carried out in a greenhouse, at the State University of Santa Cruz (UESC), in Ilhéus, BA, Brazil (14 47' 00" S, 39 02' 00" W). Photosynthetically active radiation (PAR) was monitored using quantum sensors S-LIA-M003 (Onset, USA), whereas temperature and relative humidity were monitored using combined sensors S-THB-M002 (Onset, USA). These variables were measured and stored permanently by Hobo Micro Station Data Logger H21-002 data collectors (Onset, USA).

J. curcas seeds obtained from the germplasm bank of Embrapa Agroenergia - Distrito Federal were germinated in pots (five per pot), containing $12 \mathrm{dm}^{3}$ of dystrophic yellow latosol of sandy sand textural class. After 20 days of germination, thinning was carried out, leaving only one 
plant per pot, thus starting the treatment of water deficiency, which was maintained for 42 days.

A completely randomized design with a $2 \times 9$ factorial scheme was used, whose treatments consisted of two water regimes and nine genotypes, with four replications. The water regimes were: (1) irrigation necessary to maintain soil moisture close to tank capacity (control treatment), whose matric potential ranged from -33.1 to $-15.2 \mathrm{kPa}$, and (2) irrigation just enough for maintain soil moisture at $50 \%$ of tank capacity, whose matric potential ranged from -207.0 to $-89.9 \mathrm{kPa}$. Soil moisture was determined using the gravimetric method (Casaroli \& Jong van Lier, 2008), whereas matric potential estimation was based on water retention curve. The J. curcas genotypes, in turn, were CNPAE-121, 126, 148, 168, 222, 215, 226, 298 and 299, from different regions of Brazil (Table 1).

Table 1. Geographical origin of the $J$. curcas genotypes used in the experiment

\begin{tabular}{ccccc}
\hline Genotypes & Geographical origin & Latitute $(\mathrm{S})$ & Longitude $(\mathrm{W})$ & Altitude (m) \\
\hline CNPAE-121 & Bom Jardim-RJ & $22^{\circ} 9^{\prime}$ & $42^{\circ} 25^{\prime}$ & 616 \\
CNPAE-124 & Maranhão-MA & $2^{\circ} 31^{\prime}$ & $44^{\circ} 18^{\prime}$ & 17 \\
CNAPE-148 & Candeias-BA & $12^{\circ} 40^{\prime}$ & $38^{\circ} 33^{\prime}$ & 97 \\
CNPAE-168 & Minas Gerais-MG & $18^{\circ} 0^{\prime}$ & $44^{\circ} 0^{\prime}$ & 700 \\
CNPAE-222 & Paraná-PR & $31^{\circ} 43^{\prime}$ & $60^{\circ} 31^{\prime}$ & 60 \\
CNPAE-215 & São Francisco do Glória-MG & $20^{\circ} 46^{\prime}$ & $42^{\circ} 17^{\prime}$ & 606 \\
CNPAE-226 & Água de Santa Bárbara-SP & $22^{\circ} 52^{\prime}$ & $49^{\circ} 14^{\prime}$ & 550 \\
CNPAE-298 & Sidrolândia-MS & $20^{\circ} 55^{\prime}$ & $54^{\circ} 58^{\prime}$ & 483 \\
CNPAE-299 & Rio Grande do Sul-RS & $32^{\circ} 02^{\prime}$ & $52^{\circ} 05^{\prime}$ & 950 \\
\hline
\end{tabular}

\subsection{Growth-related Traits Measurements}

At 42 days after the beginning of the imposition of water regimes, the following characteristics were measured: plant height $(\mathrm{cm})$, stem diameter $(\mathrm{mm})$, number of leaves, leaf area $\left(\mathrm{cm}^{2}\right)$, root volume $\left(\mathrm{cm}^{2}\right)$, root lenght $(\mathrm{cm})$, root total area $\left(\mathrm{cm}^{2}\right)$ and root surface area $\left(\mathrm{cm}^{2}\right)$. The leaf area was obtained by measuring the length (L) of the midrib and the maximum width $(\mathrm{W})$, whose data were used in the equation $\mathrm{AF}=(\mathrm{L} \mathrm{x} \mathrm{W}) 0.966$ proposed by Pompelli et al. (2012). Regarding the roots, the volume $\left(\mathrm{cm}^{3}\right)$, length $(\mathrm{cm})$, total area $\left(\mathrm{cm}^{2}\right)$ and surface area $\left(\mathrm{cm}^{2}\right)$ were obtained using the commercial software WinRHIZO (V5.0, Regent Instruments, Quebec, Canada). 
Five leaf discs (5 $\mathrm{mm}$ in diameter) of fully expanded leaves from the plant crown were collected, and a psychrometer (Chamber C-52, Wescor) connected to a microvoltmeter (Psy-PRO, Wescor, Logan, USA) was used to measure osmotic potential ( $\left.\Psi_{\mathrm{s}}\right)$. The $\Psi_{\mathrm{s}}$ values were corrected based on the method proposed by Wilson et al. (1979), and the osmotic adjustment (OA) was evaluated by comparing $\Psi_{\mathrm{s}}$ between control treatment and water deficit. Water use efficiency was measured based on biomass production / water consume (transpiration) ratio.

Net photosynthesis rate $\left(P_{\mathrm{N}}\right)$ and stomatal conductance $\left(g_{\mathrm{s}}\right)$ were measured based on gas exchange of fully expanded and mature leaves from plant canopy, from $8 \mathrm{~h} 30$ am to $11 \mathrm{~h} 30 \mathrm{am}$, under artificial saturating light of $1000 \mu \mathrm{mol}$ photons $\mathrm{m}^{-2} \mathrm{~s}^{-1}$ and atmospheric $\mathrm{CO}_{2}$ concentration of $\pm 390 \mu \mathrm{mol} \mathrm{mol}{ }^{-1}$, using a portable photosynthesis measurement system Li-6400 XT (LI-COR Biosciences Inc., Nebraska, USA).

Proline content was determined on leaf dry mass based on Bates et al. (1973), and the results were expressed in $\mu \mathrm{mol} \mathrm{g}^{-1} \mathrm{dry}$ mass.

Guaiacol peroxidase activity (GPX, EC 1.11.1.7) was determined according to Pirovani et al. (2008). Superoxide dismutase activity (SOD, EC 1.15.1.1), in turn, was based on its ability to inhibit the photochemical nitro blue tetrazolium (NBT) reduction. Its activity was based on the amount of extract required to cause 50\% inhibition of the NBT reduction rate (Beauchamp and Fridovich, 1971), and the results were expressed in UA kg${ }^{-1}$ dry mass. Catalase activity (CAT, EC 1.11.1.6) was determined by using Madhusudhan et al. (2003) protocol, in which the enzymatic activity is defined by the amount of enzyme required to catalyze $\mathrm{H}_{2} \mathrm{O}_{2}$ decomposition.

\subsection{Statistical Analysis}

Data were submitted to a 5\% significance test, by factorial ANOVA and when indicated, average comparisons were carried out by means of the Scott-Knott test at the same level of significance. The analyses were carried out with the aid of the SISVAR program (Ferreira, 2011).

After data collection, principal components were grouped and analyzed using morphophysiological parameters obtained by the difference $(\Delta)$ between control treatment and water deficit. To measure dissimilarity, mean Euclidean distance was calculated. To form the groupings, the UPGMA method (Unweighted Pair Group Method) was used, based on the arithmetic mean (Sneath and Sokal, 1973). The relative contribution rates for dissimilarity were calculated by the method of Singh (1981), while the cutoff point was based on the Euclidean distance. The generation of graphics was performed with Statistic statistical software version 10.0 (StatSoft, Tulsa, OK, USA). 


\section{Results}

\subsection{Growth-Related Traits}

There was no significant difference among genotypes for growth-related traits, except for stem diameter, root length, total root area and root volume (Table 2). As for water regimes, the water deficit negatively affected the leaf area (LA), whose values were about 61, 60, 64, 60 and 53\% lower than in the control, for CNPAE-126, 148, 215, 226 and 299 genotypes, respectively. Plant height $(\mathrm{H})$ under water deficit was on average $74 \%$ lower than in the control. Stem diameter (SD) under water deficit was smaller for all genotypes, except for CNPAE-299. Leaf number, in turn, did not differ among genotypes, except for CNPAE-215, which was negatively affected by water deficit (Table 2 ).

Regarding root length (RL), no difference was found among genotypes; however, observing the water regimes, RL was lower in all genotypes under water deficit, except for CNPAE-222. Comparing root total area (RTA) among genotypes in control, this was smaller in CNPAE-121, 126 and 298 than in the others; however, only CNPAE-299 was negatively affected by the water deficit. There was no difference among genotypes in relation to root surface area (RSA) in control, but CNPAE-126, 148 and 226 were negatively affected by water deficit. Comparing root volume (RV) among genotypes in control, this was higher in CNPAE-121 and 126 than in the others; as to the effect of water regimes, RV was negatively affected by water deficit in all genotypes (Table 2).

Table 2. Leaf area (LA), plant height $(\mathrm{H})$, stem diameter (SD), number of leaves (NL), root length (RL), root total area (RTA), root surface area (RSA) and root volume (RV) of young plants of J. curcas grown under full irrigation (control) and water deficit (WD) for 42 days

\begin{tabular}{|c|c|c|c|c|c|c|c|c|c|}
\hline Genotypes & & $\mathrm{LA}\left(\mathrm{cm}^{2}\right)$ & $\mathrm{H}(\mathrm{cm})$ & $\mathrm{SD}(\mathrm{cm})$ & NL & $\mathrm{RL}(\mathrm{cm})$ & $\operatorname{RTA}\left(\mathrm{cm}^{2}\right)$ & $\operatorname{RSA}\left(\mathrm{cm}^{2}\right)$ & $\mathrm{RV}\left(\mathrm{cm}^{3}\right)$ \\
\hline \multirow{2}{*}{ CNPAE-121 } & Control & $2620.5 \pm 242.1^{\mathrm{Aa}}$ & $52.0 \pm 2.4^{\mathrm{Aa}}$ & $2.4 \pm 0.06^{\mathrm{Aa}}$ & $18.7 \pm 1.0^{\mathrm{Aa}}$ & $52.2 \pm 2.6^{\mathrm{Aa}}$ & $6.3 \pm 0.3^{\mathrm{Ba}}$ & $8.2 \pm 0.1^{\mathrm{Aa}}$ & $50 \pm 3.1^{\mathrm{Aa}}$ \\
\hline & WD & $1719.7 \pm 186.0^{\mathrm{Aa}}$ & $39.0 \pm 4.0^{\mathrm{Ab}}$ & $2.1 \pm 0.11^{\mathrm{Ab}}$ & $17.2 \pm 0.6^{\mathrm{Aa}}$ & $50.3 \pm 5.4^{\mathrm{Ab}}$ & $6.4 \pm 0.1^{\mathrm{Aa}}$ & $7.8 \pm 0.9^{\mathrm{Aa}}$ & $32 \pm 4.8^{\mathrm{Ab}}$ \\
\hline \multirow{2}{*}{ CNPAE-126 } & Control & $2799.6 \pm 344.1^{\mathrm{Aa}}$ & $48.5 \pm 2.1^{\mathrm{Aa}}$ & $2.5 \pm 0.08^{\mathrm{Aa}}$ & $19.0 \pm 0.7^{\mathrm{Aa}}$ & $57.7 \pm 1.2^{\mathrm{Aa}}$ & $5.9 \pm 0.4^{\mathrm{Ba}}$ & $9.8 \pm 0.6^{\mathrm{Aa}}$ & $57 \pm 3.0^{\mathrm{Aa}}$ \\
\hline & WD & $1712.5 \pm 203.3^{\mathrm{Ab}}$ & $33.2 \pm 3.6^{\mathrm{Ab}}$ & $1.9 \pm 0.11^{\mathrm{Ab}}$ & $14.5 \pm 0.8^{\mathrm{Aa}}$ & $47.2 \pm 1.8^{\mathrm{Ab}}$ & $6.1 \pm 0.3^{\mathrm{Aa}}$ & $7.6 \pm 0.1^{\mathrm{Ab}}$ & $20 \pm 2.7^{\mathrm{Ab}}$ \\
\hline \multirow{2}{*}{ CNPAE-148 } & Control & $2922.3 \pm 537.4^{\mathrm{Aa}}$ & $52.5 \pm 5.6^{\mathrm{Aa}}$ & $2.3 \pm 0.12^{\mathrm{Aa}}$ & $21.2 \pm 4.0^{\mathrm{Aa}}$ & $99.1 \pm 14.2^{\mathrm{Aa}}$ & $9.1 \pm 1.2^{\mathrm{Aa}}$ & $10.8 \pm 0.4^{\mathrm{Aa}}$ & $42 \pm 5.8^{\mathrm{Ba}}$ \\
\hline & WD & $1740.1 \pm 25$ & $37.7 \pm$ & $2.0 \pm 0.11^{\mathrm{Bb}}$ & $15.7 \pm 1.2^{\mathrm{Aa}}$ & $57.7 \pm 7.1^{\mathrm{Ab}}$ & $6.8 \pm 0.9^{\mathrm{Aa}}$ & $8.4 \pm 0.1^{\mathrm{Ab}}$ & $16 \pm 2.9^{\mathrm{Ab}}$ \\
\hline \multirow{2}{*}{ CNPAE-168 } & Control & $2860.7 \pm 1$ & $51.0 \pm 2.6^{\mathrm{Aa}}$ & $2.5 \pm 0.04^{\mathrm{Aa}}$ & $18.5 \pm 0.8^{\mathrm{Aa}}$ & $87.4 \pm 16.9^{\mathrm{Aa}}$ & $8.3 \pm 1.1^{\mathrm{Aa}}$ & $10.4 \pm 0.7^{\mathrm{Aa}}$ & $40 \pm 2.7^{\mathrm{Ba}}$ \\
\hline & WD & $2066.5 \pm 223.2^{\mathrm{Aa}}$ & $39.0 \pm 3.5^{\mathrm{Ab}}$ & $2.1 \pm 0.02^{\mathrm{Ab}}$ & $15.5 \pm 0.6^{\mathrm{Aa}}$ & $64.5 \pm 8.1^{\mathrm{Ab}}$ & $7.2 \pm 0.9^{\mathrm{Ba}}$ & $8.9 \pm 0.1^{\mathrm{Aa}}$ & $24 \pm 7.4^{\mathrm{Ab}}$ \\
\hline \multirow{2}{*}{ CNPAE-215 } & Control & $2767.5 \pm 352.4^{\mathrm{Aa}}$ & $47.2 \pm 2.8^{\mathrm{Aa}}$ & $2.4 \pm 0.12^{\mathrm{Aa}}$ & $21.0 \pm 3.3^{\mathrm{Aa}}$ & $77.3 \pm 6.9^{\mathrm{Aa}}$ & $7.6 \pm 0.1^{\mathrm{Aa}}$ & $10.1 \pm 0.7^{\mathrm{Aa}}$ & $33 \pm 2.5^{\mathrm{Ba}}$ \\
\hline & & $1768.6 \pm 157.7^{\mathrm{Ab}}$ & $37.5 \pm 2.6^{\mathrm{Ab}}$ & $2.0 \pm 0.10^{\mathrm{Ab}}$ & $15.2 \pm 0.6^{\mathrm{Ab}}$ & $59.8 \pm 14.8^{\mathrm{Ab}}$ & $6.2 \pm 0.9^{\mathrm{Ba}}$ & & $\pm 2.5^{\mathrm{Ab}}$ \\
\hline \multirow{2}{*}{ CNPAE-222 } & Control & $3655.8 \pm 602.7^{\text {Aa }}$ & $58.5 \pm 1.5^{\mathrm{Aa}}$ & $2.5 \pm 0.12^{\mathrm{Aa}}$ & $28.5 \pm 5.8^{\mathrm{Aa}}$ & $80.9 \pm 2.5^{\mathrm{Aa}}$ & $8.1 \pm 0.3^{\mathrm{Aa}}$ & $9.9 \pm 0.6^{\mathrm{Aa}}$ & $44 \pm 5.0^{\mathrm{Ba}}$ \\
\hline & WD & $1962.2 \pm 108.2^{\mathrm{Aa}}$ & $42.5 \pm 1.3^{\mathrm{Ab}}$ & $2.0 \pm 0.06^{\mathrm{Ab}}$ & $18.2 \pm 1.9^{\mathrm{Aa}}$ & $65.4 \pm 6.1^{\mathrm{Aa}}$ & $7.4 \pm 0.7^{\mathrm{Ba}}$ & $8.8 \pm 0.2^{\mathrm{Aa}}$ & $16 \pm 2.4^{\mathrm{Ab}}$ \\
\hline \multirow{2}{*}{ CNPAE-226 } & Control & $2240.3 \pm 182.4^{\mathrm{Aa}}$ & $52.1 \pm 3.7^{\mathrm{Aa}}$ & $2.3 \pm 0.13^{\mathrm{Aa}}$ & $18.0 \pm 1.0^{\mathrm{Aa}}$ & $100.8 \pm 20.7^{\mathrm{Aa}}$ & $9.7 \pm 1.3^{\mathrm{Aa}}$ & $10.1 \pm 0.6^{\mathrm{Aa}}$ & $37 \pm 2.4^{\mathrm{Ba}}$ \\
\hline & WD & $1330.4 \pm 168.6^{\mathrm{Ab}}$ & $30.7 \pm 4.4^{\mathrm{Ab}}$ & $1.9 \pm 0.12^{\mathrm{Bb}}$ & $14.5 \pm 0.6^{\mathrm{Aa}}$ & $59.9 \pm 8.4^{\mathrm{Ab}}$ & $7.3 \pm 0.7^{\mathrm{Aa}}$ & $8.0 \pm 0.3^{\mathrm{Ab}}$ & $11 \pm 6.4^{\mathrm{Ab}}$ \\
\hline \multirow{2}{*}{ CNPAE-298 } & Control & $2217.5 \pm 75.3^{\mathrm{Aa}}$ & $50.2 \pm 1.3^{\mathrm{Aa}}$ & $2.3 \pm 0.04^{\mathrm{Aa}}$ & $17.7 \pm 0.4^{\mathrm{Aa}}$ & $77.9 \pm 8.0^{\mathrm{Aa}}$ & $8.2 \pm 0.6^{\mathrm{Ba}}$ & $9.4 \pm 0.3^{\mathrm{Aa}}$ & $37 \pm 2.0^{\mathrm{Ba}}$ \\
\hline & WD & $1913.0 \pm 243.2^{\mathrm{Aa}}$ & $36.6 \pm 2.5^{\mathrm{Ab}}$ & $1.8 \pm 0.06^{\mathrm{Bb}}$ & $16.2 \pm 1.7^{\mathrm{Aa}}$ & $55.7 \pm 1.1^{\mathrm{Ab}}$ & $7.0 \pm 0.4^{\mathrm{Aa}}$ & $7.9 \pm 0.5^{\mathrm{Aa}}$ & $18 \pm 3.3^{\mathrm{Ab}}$ \\
\hline \multirow{2}{*}{ CNPAE-299 } & Control & $3010.5 \pm 646.6^{\mathrm{Aa}}$ & $48.7 \pm 2.5^{\mathrm{Aa}}$ & $2.3 \pm 0.11^{\mathrm{Aa}}$ & $21.5 \pm 3.2^{\mathrm{Aa}}$ & $116.6 \pm 13.3^{\text {Aa }}$ & $11.9 \pm 1.3^{\mathrm{Aa}}$ & $9.7 \pm 0.1^{\mathrm{Aa}}$ & $36 \pm 6.2^{\mathrm{Ba}}$ \\
\hline & WD & $1603.5 \pm 127.9^{\mathrm{Ab}}$ & $38.5 \pm 2.6^{\mathrm{Ab}}$ & $2.1 \pm 0.13^{\mathrm{Aa}}$ & $15.2 \pm 0.2^{\mathrm{Aa}}$ & $58.7 \pm 14.0^{\mathrm{Ab}}$ & $6.3 \pm 1.2^{\mathrm{Ab}}$ & $9.1 \pm 0.5^{\mathrm{Aa}}$ & $19 \pm 3.3^{\mathrm{Ab}}$ \\
\hline
\end{tabular}

Values are mean ( \pm standard error) of four replicates. Lower case indicate significant difference between treatments within each genotype by the F-test $(\mathrm{p}<0.05)$ and capital letters indicate significant difference among genotypes within each treatment by the Scott-Knott test $(\mathrm{p}<0.05)$. 
There was significant difference among genotypes for almost all physiological traits, except for water use efficiency (WUE) (Table 3). Regarding the effects of water regimes, an increase in proline content induced by water deficit was observed in genotypes CNPAE-121, 222 and 226. Leaf osmotic potential had a decrease in all genotypes. Net photosynthesis $\left(P_{\mathrm{N}}\right)$ was lower in CNPAE-121, 126, 222 and 299, but it was not affected in 146, 168, 215, 228 and 298. Stomatal conductance $\left(g_{\mathrm{s}}\right)$ was lower in CNPAE-121, 126, 148, 215 and 299, but it was not affected in 168, 222, 226 and 298. WUE had no changes in almost all genotypes, but it was higher under water deficit in CNPAE-226 and 298.

Antioxidative enzymatic activity under water deficit showed different performances, depending on the genotype and the enzyme (Table 3). Guaiacol peroxidase (GPX) activity was higher in CNPAE-121, 148, 168, 226 and 299 genotypes, but remained unchanged at 126, 215, 222 and 298. Superoxide dismutase (SOD) activity, in turn, was higher in CNPAE-121, 222, 226 and 299, but remained unchanged in 126, 148, 168, 215 and 298. Finally, catalase (CAT) activity was higher in CNPAE-126, 215, 222, 226, 298 and 299, but remained unchanged at 121, 148 and 168. CNPAE-226 and 299 were the only genotypes whose antioxidant activity of the three enzymes increased under water deficit.

Table 3 Leaf proline content $(\mathrm{PRO})$, leaf osmotic potential $\left(\Psi_{\mathrm{s}}\right)$, net photosynthesis $\left(P_{\mathrm{N}}\right)$, stomatal conductance $\left(g_{\mathrm{s}}\right)$, guaiacol peroxidase (GPX), superoxide dismutase (SOD), catalase (CAT) and water use efficiency (WUE) of young plants of $J$. curcas grown under full irrigation (control) and water deficit (WD) for 42 days

\begin{tabular}{|c|c|c|c|c|c|c|c|c|c|}
\hline Genotyp & & $\begin{array}{l}\text { PRO } \\
(\mu \mathrm{mol} \mathrm{g} \\
\left.\mathrm{DW}^{-1}\right)\end{array}$ & $\begin{array}{c}\Psi_{\mathrm{s}} \\
(-\mathrm{MPa})\end{array}$ & $\begin{array}{c}P_{\mathrm{N}} \\
\left(\mu \mathrm{mol} \mathrm{CO} \mathrm{CO}_{2}\right. \\
\left.\mathrm{m}^{-2} \mathrm{~s}^{-1}\right)\end{array}$ & $\begin{array}{c}g_{\mathrm{s}} \\
\left(\mathrm{mol} \mathrm{H}_{2} \mathrm{O}\right. \\
\left.\mathrm{m}^{-2} \mathrm{~s}^{-1}\right)\end{array}$ & $\begin{array}{c}\text { GPX } \\
\left(\mathrm{mmol} \mathrm{h}^{-1} \mathrm{~kg}^{-1}\right. \\
\text { DW })\end{array}$ & $\begin{array}{c}\text { SOD } \\
\text { (UA kg }{ }^{-1} \\
\text { DW) }\end{array}$ & $\begin{array}{c}\mathrm{CAT} \\
\left(\mu \mathrm{mol} \mathrm{H} \mathrm{O}_{2}\right. \\
\mathrm{kg}^{-1} \mathrm{DW} \\
\left.\min ^{-1}\right) \\
\end{array}$ & $\begin{array}{l}\text { WUE } \\
\left(\mathrm{kg} \mathrm{m}^{-3}\right)\end{array}$ \\
\hline \multirow{2}{*}{ CNPAE-121 } & & & & & & & & $0.07 \pm 0.002^{\mathrm{Aa}}$ & \\
\hline & & & & & & $8^{\mathrm{Da}}$ & $4 \pm 0.017^{\mathrm{Ba}}$ & $0.07 \pm 0.004^{\mathrm{Ba}}$ & \\
\hline \multirow{2}{*}{ CNPAE-126 } & & & & & & & & & \\
\hline & & & & & & & $2^{\mathrm{Ba}}$ & & \\
\hline \multirow{2}{*}{ CNPAE-148 } & & & & & & & Aa & & \\
\hline & & & & & & & & & \\
\hline \multirow{2}{*}{ CNPAE-168 } & Cont & & & & & & & & \\
\hline & & & & & & & & & \\
\hline \multirow{2}{*}{ CNPAE-215 } & & & & & & & & & $.4^{\mathrm{Aa}}$ \\
\hline & & & & & & & & & \\
\hline \multirow{2}{*}{ CNPAE-222 } & Control & & $8^{\mathrm{Ab}}$ & $11.8 \pm 0$ & $0.16 \pm$ & $0.06 \pm 0$ & $0.16 \pm 0$. & $2^{\mathrm{Cb}}$ & \\
\hline & & $0.22 \pm 0$ & & & $0.13 \pm 0.0$ & & $0.20 \pm 0.008^{\mathrm{Ca}}$ & $0.07 \pm 0.006^{\mathrm{Ba}}$ & $7.5 \pm 0.4^{\mathrm{Aa}}$ \\
\hline \multirow{2}{*}{ CNPAE-226 } & Cont & & & & & & & $0.03 \pm 0.001^{\mathrm{Cb}}$ & \\
\hline & & $0.35 \pm 0.03^{\mathrm{Aa}}$ & $1.70 \pm 0.08^{\mathrm{Ba}}$ & $8.9 \pm 1.84^{\mathrm{Ba}}$ & $0.08 \pm 0.02^{\mathrm{Ca}}$ & $0.09 \pm 0.003^{\mathrm{Ba}}$ & $0.21 \pm 0.006^{\mathrm{Ca}}$ & $0.07 \pm 0.004^{\mathrm{Ba}}$ & $12.8 \pm 2.5^{\mathrm{Aa}}$ \\
\hline \multirow{2}{*}{ CNPAE-298 } & Control & $0.13 \pm 0.01^{\mathrm{Ba}}$ & $1.24 \pm 0.09^{\mathrm{Bb}}$ & $10.6 \pm 0.47^{\mathrm{Ba}}$ & $0.09 \pm 0.02^{\mathrm{Ca}}$ & $0.01 \pm 0.001^{\mathrm{Da}}$ & $0.16 \pm 0.006^{\mathrm{Ba}}$ & $0.06 \pm 0.001^{\mathrm{Bb}}$ & $8.2 \pm 0.3^{\mathrm{Ab}}$ \\
\hline & WD & $0.17 \pm 0.02^{\mathrm{Ba}}$ & $1.69 \pm 0.08^{\mathrm{Ba}}$ & $4.6 \pm 0.43^{\mathrm{Ca}}$ & $0.03 \pm 0.01^{\mathrm{Ca}}$ & $0.003 \pm 0.001^{\mathrm{Fa}}$ & $0.16 \pm 0.007^{\mathrm{Da}}$ & $0.09 \pm 0.003^{\mathrm{Aa}}$ & $14.9 \pm 3.5^{\mathrm{Aa}}$ \\
\hline \multirow{2}{*}{ CNPAE-299 } & Contro & $0.09 \pm 0.02^{\mathrm{Ba}}$ & $1.10 \pm 0.07^{\mathrm{Bb}}$ & $19.1 \pm 0.64^{\mathrm{Aa}}$ & $0.37 \pm 0.06^{\mathrm{Aa}}$ & $0.01 \pm 0.002^{\mathrm{Da}}$ & $0.16 \pm 0.004^{\mathrm{Bb}}$ & $0.06 \pm 0.003^{\mathrm{Bb}}$ & $9.2 \pm 1.2^{\mathrm{Aa}}$ \\
\hline & WD & $0.12 \pm 0.01^{\mathrm{Ba}}$ & $1.72 \pm 0.07^{\mathrm{Ba}}$ & $7.2 \pm 0.82^{\mathrm{Cb}}$ & $0.04 \pm 0.01^{\mathrm{Cb}}$ & $0.01 \pm 0.006^{\mathrm{Ea}}$ & $0.46 \pm 0.036^{\mathrm{Aa}}$ & $0.09 \pm 0.005^{\mathrm{Aa}}$ & $8.2 \pm 0.3^{\mathrm{Aa}}$ \\
\hline
\end{tabular}

Values are mean ( \pm standard error) of four replicates. Lower case indicate differences between treatments within each genotype by the F-test $(p<0.05)$ and capital letters indicate significant differences among genotypes within each treatment by the Scott-Knott test $(\mathrm{p}<$ $0.05)$. 
3.3 Multivariate Analysis and Principal Components

The analysis of grouping and graphic dispersion based on concomitant observation of growth-related and physiological traits indicated divergences among the nine genotypes.

The dendrogram produced from this analysis resulted in the following groups of genotypes: Group I, formed by CNPAE-121 and 168; Group II, by CNPAE-298; Group III, by CNPAE-126, 148, 226 and 215; Group IV, by CNPAE-222; and Group V, by CNPAE-299 (Figure 1).

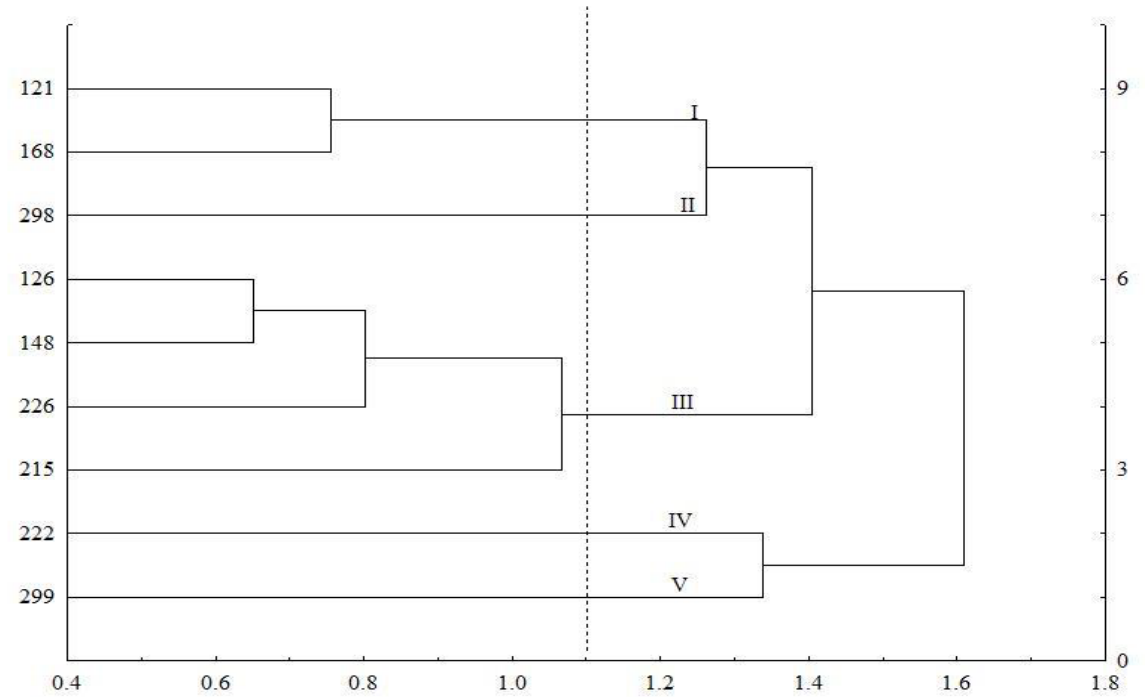

Figure 1. Dendrogram produced from grouping analysis and graphic dispersion referring to growth-related traits in nine genotypes of $J$. curcas subjected to soil water deficit for 42 days, based on the Euclidean distance between control and water deficit treatments

The most determinant trait for genetic dissimilarity and groups formation was the root total area $(18.9 \%)$, followed by plant height $(17.9 \%)$ and number of leaves $(17.6 \%)$. On the other hand, leaf area $(5.0 \%)$, root length $(5.6 \%)$ and stem diameter $(6.9 \%)$ were less influential for genetic dissimilarity (Table 4).

Table 4. Relative contribution (S.j) of growth-related traits on genetic dissimilarity (Singh, 1981) in nine genotypes of J. curcas

\begin{tabular}{ccc}
\hline Growth-related traits & S.j & Relative contribution $(\%)$ \\
\hline Leaf area & 6.3 & 3.9 \\
Plant height & 33.9 & 21.1 \\
Stem diameter & 6.34 & 3.9 \\
Number of leaf & 31.3 & 19.5 \\
Root lenght & 5.42 & 3.3 \\
Root total area & 33.9 & 21.4 \\
Root surface area & 13.1 & 8.1 \\
Root volume & 30.2 & 18.8 \\
\hline
\end{tabular}




\section{Macrothink

The two principal components of genetic dissimilarity, that is, the two most influential growth-related traits, accounted for $65.54 \%$ of the total variation $-37.65 \%$ for the first component and $27.89 \%$ for the second (Figure 2).

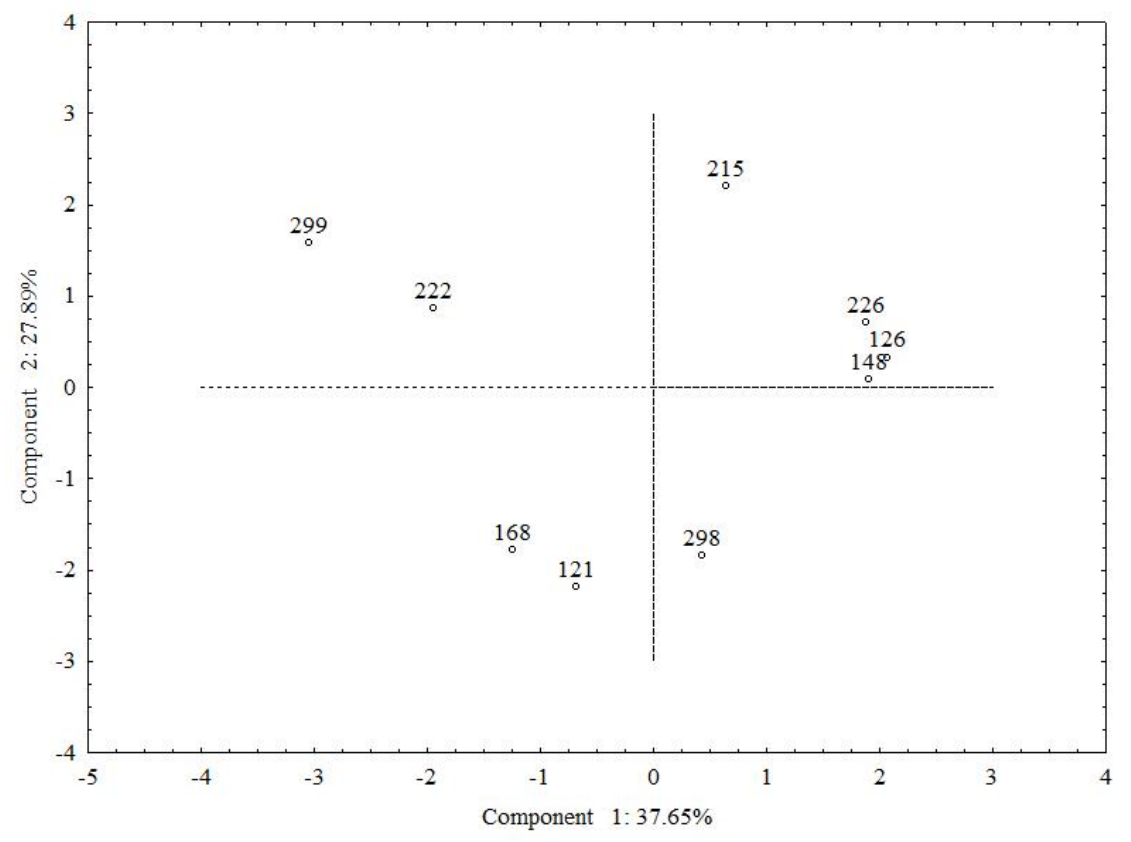

Figure 2. Principal components analysis of genetic dissimilarity in nine genotypes of $J$. curcas submitted to soil water deficit for 42 days, based on growth-related traits

The analysis of the dendrogram (Figure 3) allows the identification of the following groups for cluster analysis, based on physiological characteristics: Group I, formed by the CNPAE-121 genotype; Group II, formed by CNPAE-126 and 222; Group III, formed by CNPAE-148, 168 and 215; Group IV, formed by CNPAE-226; Group V, formed by CNPAE-298; and Group VI, formed by CNPAE-299.

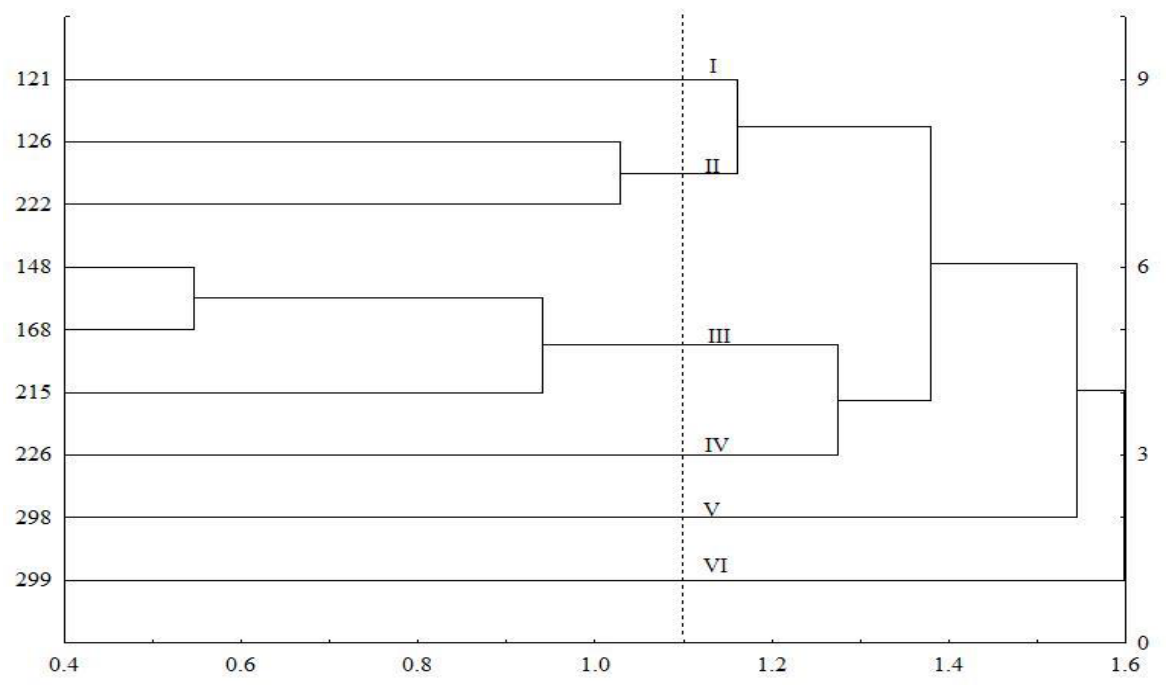

Figure 3. Euclidean dendrogram for nine genotypes accessions of J. curcas submitted to soil water deficit for 42 days, based on growth-related traits 


\section{Macrothink

The relative contribution of physiological traits was also analyzed, to identify the most influential traits for the groups formation. It was found that $g_{\text {s }}$ contributed $24.9 \%$, followed by GPX with $20.9 \%$. Among the physiological variables, CAT was the one that least contributed to the groups formation $(0.7 \%)$, followed by WUE (7.4\%) (Table 5).

Table 5. Relative contribution (S.j) of physiological traits on genetic dissimilarity (Singh, 1981) in nine genotypes of $J$. curcas

\begin{tabular}{ccc}
\hline Physiological traits & S.j & Relative contribution (\%) \\
\hline Proline content & 23 & 15.6 \\
Osmotic adjustment & 25.9 & 17.5 \\
Net photosynthesis & 15.1 & 10.2 \\
Stomatal conductance & 37 & 24.9 \\
Guaiacol peroxidase activity & 31 & 20.9 \\
Superoxide dismutase activity & 3.84 & 2.6 \\
Catalase activity & 1.11 & 0.7 \\
Water use efficiency & 10.9 & 7.4 \\
\hline
\end{tabular}

The two principal physiological components of genetic dissimilarity accounted for $56.02 \%$ of the total variation -34.50 for the first component and $21.52 \%$ for the second (Figure 4 ).

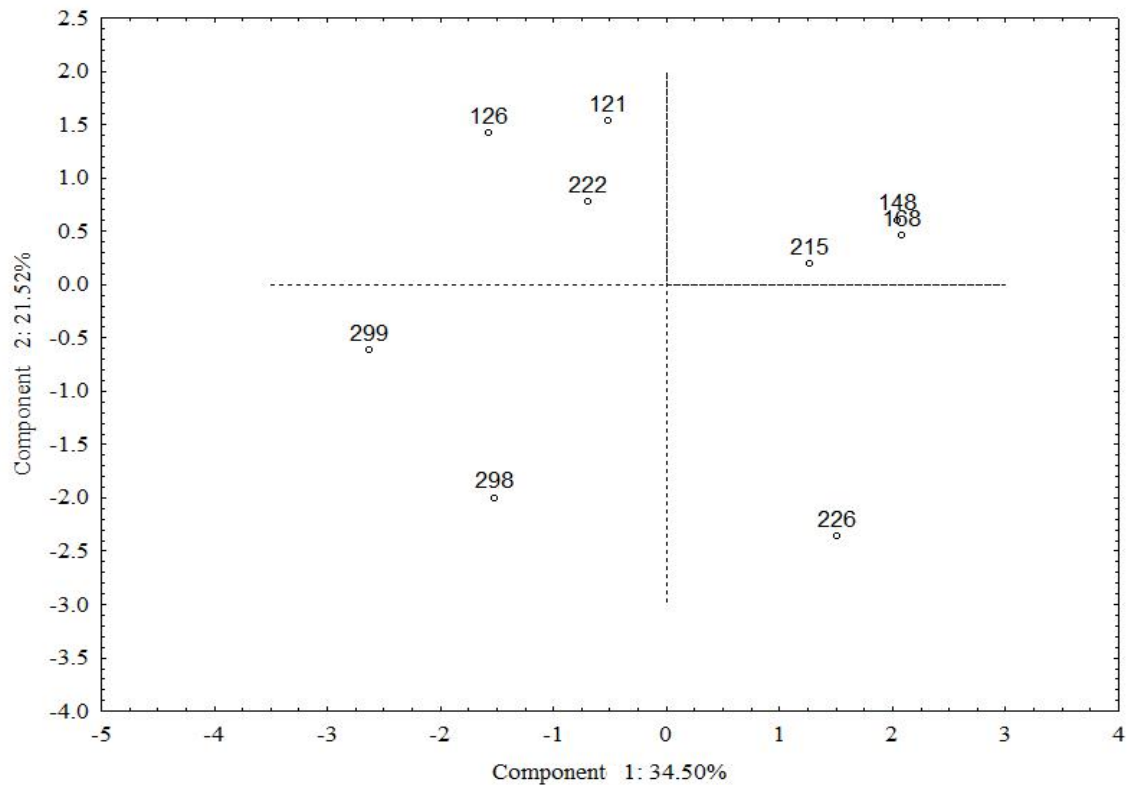

Figure 4. Principal components analysis of genetic dissimilarity in nine genotypes of $J$. curcas submitted to soil water deficit for 42 days, based on physiological traits 


\section{Discussion}

This study is an assesment on behaviour of nine genotypes of $J$. curcas under water deficit, based on changes in growth-related and physiological traits. Physiological responses can be influenced by various internal and external stimuli, which induce morphological and biochemical adjustments, to ensure sustainable plant development (Kumar et al., 2014).

Our results showed that all genotypes had both morphological and physiological traits negatively affected by water deficit (Tables 3 and 4), similarly to results reported by several other researchers (Santana et al., 2015; Oliveira et al., 2016; Silva et al., 2016, 2019; Yin et al., 2016; Santana et al., 2017). Our results indicated growth inhibition and stomatal restriction to $P_{\mathrm{N}}$ under water deficit. Thus, mechanisms should be developed to improve $J$. curcas tolerance to water restrictions, such as changes in plant height, stomatal closure and increased WUE (Yin et al., 2016).

Environmental stresses cause metabolic changes in plants, producing reactive oxygen species (ROS), which result in oxidative cell damage (Shu et al., 2012; Ren et al., 2018). To protect against oxidative damage, plant cells produce antioxidant enzymes, such as superoxide dismutase (SOD), peroxidases (POD) and catalase (CAT). The increase in antioxidant enzymes activity can be considered as an important strategy of cellular defense against oxidative stress (Liang and Wang, 2013; Ju et al., 2017; Ren et al., 2018).

SOD activity increased significantly in genotypes under water deficit (Table 5), and was greater in the CNPAE-299 genotype (Table 3). SOD is assumed as the first line of defense against the toxic effects of high levels of ROS. The activity of GPX and CAT, in turn, also increased under water deficit and was greater in the genotypes CNPAE-148, 298 and 299, respectively, in which they formed two distinct groups, in terms of contribution to the genetic diversity of $J$. curcas. Due to the toxic effect of hydrogen peroxide $\left(\mathrm{H}_{2} \mathrm{O}_{2}\right)$, GPX and CAT also play an important role in the antioxidant defense system of plants, as they help convert $\mathrm{H}_{2} \mathrm{O}_{2}$ into $\mathrm{H}_{2} \mathrm{O}$ and $\mathrm{O}_{2}$. Increased activity of antioxidant enzymes under water deficit was also found by Silva et al. (2016), who also assessed the same genotypes of J. curcas used in the present study.

For cluster analysis, sample units are grouped into groups, based on some classification criteria in order to obtain low homogeneity and high heterogeneity (Prado et al., 2017). The analysis of genetic distance and clustering are important tools to assess the relative contribution of different characteristics to total diversity, quantify the degree of divergence among populations or accessions and select divergent or genetically similar parents (Kaushik et al., 2007). In the present study, it was observed that genotypes from different geographical origins were grouped (Figure1). These results are consistent with those obtained by Kaushik et al. (2007) and indicate that geographic diversity does not necessarily represent genetic diversity among accessions collected. For, although some genotypes belong to the same geographical region, they could have undergone changes for different characteristics in their selection.

Results suggest a broad genetic basis, since the values of genetic distance ranged from 0.2 to 0.22 , for growth-related traits (Figure 1), and from 0.4 to 1.6 , for physiological traits (Figure 
2). Wide genetic variability in morphological characteristics, was also reported by Wani et al. (2012). This high diversity represents an important resource for future crossings in breeding programs. As described by Rocha et al. (2012), morpho-agronomic characterizations have shown significant genetic variability for J. curcas, in contrast to the low diversity that is obtained when molecular markers are used (Rosado et al., 2010). Similar results have also been reported for some Brazilian (Santos et al., 2010), Mesoamerican (Medina et al., 2011) and Indian (Tatikonda et al., 2009) populations.

Due to genotype variability, the dendrogram did not show clusters by geographic origin, which can be attributed to the fact that each group is composed by different genotypes. Similar results were obtained in studies of Indian accesses for J. curcas (Kaushik et al., 2007; Jun-Ling et al., 2010; Tripathi et al., 2015). Ricci et al. (2012) studied plants of J. curcas collected from different geographical origins (Brazil, Cape Verde, Cuba, Mozambique and Senegal) and identified the formation of two groups, one of them composed of plants from Brazil, Mozambique and Senegal, and another, by plants from Cuba and Cape Verde. These authors concluded that geographic diversity does not necessarily correspond to genetic diversity. According to Ferrão et al. (2002), studies on genetic diversity are important for plant breeding, because they provide parameters to identify parents that enable the emergence of superior genetic materials for crossing and knowledge about genetic bases of the assessed population.

Principal components analysis is a classic method of reducing dimensionality, which transforms a set of original variables into a smaller set of uncorrelated variables. This method is linear because the new components are a linear combination of the original data (Abdi and Williams, 2010). They are applied to determine the most important traits and attributes in each dimension (Hair et al., 2010).

In the present study, the relative contributions of the two principal components of growth-related and physiological traits were 65.54 and $56.02 \%$, respectively (Figure 2 and 4). According to Rencher (2002), at least $70 \%$ of total variance must be accounted for by the first and second principal components. However, studies report that the analysis of principal components has been shown to be effective for the assessment of genetic diversity, even when this limit is not reached. The results showed that root total area, plant height and number of leaves were the growth-related traits most influential for genetic diversity (Table 4). On the other hand, studies by Laviola et al. (2011) on genotypes of $J$. curcas showed that stem diameter and plant height contributed 12 and $11 \%$, respectively, to genetic diversity. Knowing the variability of morphological characteristics is essential to reach genetic gains in breeding programs, particularly for the selection of elite genotypes (Basu et al., 2017).

CNPAE-126 and 148 were the most similar genotypes, among the growth-related traits, based on the shortest distance among the genotypes (Figure 3). For the groups formation, $g_{\mathrm{s}}$ and GPX were the most influential physiological traits (Table 5). The CNPAE-121, 226, 298 and 299 genotypes were the most divergent, based on physiological traits. Therefore, these genotypes can be used for bi-parental crossing, since this contrast can potentiate the obtaining of highly segregating populations and a possible obtaining of transgression genotypes for various traits (Belete et al., 2011). 


\section{Macrothink Institute ${ }^{\mathrm{TM}}$}

Studies have reported that the crossing of populations from clusters that exhibit maximum distance among the groups and a high mean value for agronomic traits could generate more divergent plants (Kaushik et al., 2007; Srivastava et al., 2011; Shabanimofrad et al., 2013). Furthermore, Shen et al. (2010) studying 38 genotypes from different regions of China and Indonesia, also observed that they are mixed among the groups of the dendrogram generated by UPGMA method, which is the same method used in this research.

One of the approaches to the genetic improvement of $J$. curcas in this study was the verification of growth-related and physiological traits, in order to improve some agronomic characteristics, such as tolerance to adverse conditions, especially to water deficit. Identifying descriptors with little or no influence from the environment is essential to diverge and protect future populations of $J$. curcas, since quantitative descriptors, such as morphophysiological traits, are greatly influenced by genotype x environment interactions. Therefore, the study of multivariate analyzes must be essential to identify and assess descriptors for plant breeding, where the genetic divergence between genotypes is considered and traits could be analyzed as a group.

\section{Conclusions}

The variability that was revealed in the present research can be informative from the point of view of management and conservation in genotypes of $J$. curcas. The morphophysiological traits showed that CNPAE-298 and 299 are the most distant genotypes among the plant groups. Root area, plant height, $g_{s}$ and GPX were the most determining traits for dissimilarity among genotypes of $J$. curcas under water deficit, and they should be prioritized when the choice of genotypes, in further studies on this species.

\section{Acknowledgements}

Leandro D. da Silva thanks the Coordenação de Aperfeiçoamento de Pessoal de Nível Superior (CAPES, Brazil), for the Post-Doctoral scholarship. Fábio P. Gomes thanks the Conselho Nacional de Desenvolvimento Científico e Tecnológico (CNPq, Brazil), for the scientific productivity scholarship.

\section{References}

Abdi, H., \& Williams, L. J. (2010). Principal component analysis. Wiley Interdisciplinary Reviews: Computacional Statistics, 2, 433-459. https://doi.org/10.1002/wics.101

Basha, S. D., \& Sujatha, M. (2007). Inter and intra-population variability of Jatropha curcas (L.) characterized by RAPD and ISSR markers and development of population-specific SCAR markers. Euphytica, 156, 375-386. https://doi.org/10.1007/s10681-007-9387-5

Basha, S. D., Francis, G., Makkar, H. P. S., Becker, K., \& Sujatha, M. (2009). A comparative study of biochemical traits and molecular markers for assessment of genetic relationships between Jatropha curcas L. germplasm from different countries. Plant Science, 176, 812-823. https://doi.org/10.1016/j.plantsci.2009.03.008

Basu, A., Rao, L., \& Sahoo, K. (2017). Morphometric characterization of Jatropha curcas germplasm of North-East India. African Journal of Biotechnology, 16, 648-656. 
https://doi.org/10.5897/AJB2016.15428

2020, Vol. 8, No. 3

Bates, L. S., Waldern, R. P., \& Teare, I. K. (1973). Rapid Determination of Free Proline for Water Stress Studies. Plant Soil, 39, 205-208. https://doi.org/10.1007/BF00018060

Beauchamp, C., \& Fridovich, I. (1971). Superoxide dismutase: improved assays and an assay applicable to acrylamide gels. Analytical Biochemistry, 44, 276-287. https://doi.org/10.1016/0003-2697(71)90370-8

Belete, Y. S., Kebede, S. A., \& Gemelal, A. W. (2011). Multivariate analysis of genetic divergence among Ethiopian Mustard (Brassica carinata A. Brun) genotypes in relation to seed oil quality traits. International Journal Agricultural Research, 6(6), 494-503. http://doi.org/10.3923/ijar.2011.494.503

Casaroli, D., \& de Jong van Lier, Q. (2008). Critérios para determinação da capacidade de vaso. Revista Brasileira de Ciencia do Solo, 32(1), 59-66. http://doi.org/10.1590/S0100-06832008000100007

Clegg, K. M. (1956). The application of the anthrone reagente to the estimation of starch in cereals. Journal of Science Food and Agriculture, 3, 40-44. https://doi.org/10.1002/jsfa.2740070108

Das, S., Misra, R. C., Mahapatra, A. K., Gantayat, B. P., \& Pattnaik, R. K. (2010). Genetic variability, character association and path analysis in Jatropha curcas. World Applied Sciences Journal, 8(11), 1304-1308.

Dias, L. A. S., Misso, R. F., Ribeiro, R. M., Freitas, R. G., \& Dias, P. F. S. (2009). Agrocombustíveis: perspectivas futuras. Bahia: Análise Dados, 18, 539-547.

Ferrão, M. A. G., Vieira, C., Cruz, C. D., \& Cardoso, A. A. (2002). Divergência genética em feijoeiro em condições de inverno tropical. Pesquisa Agropecuária Brasileira, 7(8), 1089-1098. https://doi.org/10.1590/S0100-204X2002000800006

Ferreira, D. F. (2011). Sisvar: a computer statistical analysis system. Ciência $e$ Agrotecnologia, 35, 1039-1042.

Flood, P. J., Harbinson, J., \& Aarts, M. G. M. (2011). Natural genetic variation in plant photosynthesis. Trends in Plant Science, 16(6), 327-335.

https://doi.org/10.1016/j.tplants.2011.02.005

Freitas, R. G., Missio, R. F., Matos, F. S., Resende, M. D. V., \& Dias, L. A. S. (2011). Genetic evaluation of Jatropha curcas: an important oilseed for biodiesel production. Genentics and Molecular Research, 10(3), 1490-1498. http://doi.org/10.4238/vol10-3gmr1146

Gairola, K. C., Nautiyal, A. R., Sharma, G. \& Dwivedi, A. K. (2011). Variability in seed characteristics of Jatropha curcas L. from hill region of Uttarakhand. Bulletin of Environment, Pharmacology \& Life Sciences, 1, 64-69.

Hair, J. F. J., Black, W. C., Babin, B. J., \& Anderson, R. E. (2010). Multivariate data analysis. Seventh Edition. Prentice Hall, Upper Saddle River, New Jersey. p 23-26. 
https://doi.org/10.1590/S1413-70542011000600001

Jongschaap, R. E. E., Corré, W. J., Bindraban, P. S., \& Brandenburg, W. A. (2007). Claims and facts on Jatropha curcas L.: Global Jatropha curcas evaluation, breeding and propagation programme. Plant Research International, 158.

Ju, S. M., Wang, L. P., Yin, N. N., Li, D., Wang, Y. K., \& Zhang, C. Y. (2017). Silicon alleviates simulated acid rain stress of Oryza sativa L. seedlings by adjusting physiology activity and mineral nutrients. Protoplasma, 254(6), 2071-2081. http://doi.org/10.1007/s00709-017-1099-7

Jun-Ling, S., Xiang-Nan, J., Hui-Qun, N., Pei-Guang, S., Shi-Hui, N., \& Xiao-Yang, C. (2010). AFLP analysis of genetic diversity of Jatropha curcas grown in Hainan, China. Trees, 24(3), 455-462. http://doi.org/10.1007/s00468-010-0413-1

Kai, C., \& Ming, G. (2011). Changes of water status and different responses of osmoregulants in Jatropha curcas L. seedlings to air drought stress. Agriculture Science and Technology, 12(3), 343-346.

Kaushik, N., Kumar, K., Kumar, S., Kaushik, N., \& Roy, S. (2007). Genetic variability and divergence studies in seed traits and oil content of Jatropha (Jatropha curcas L.) accessions. Biomass and Bioenergy, 31, 497-502. https://doi.org/10.1016/j.biombioe.2007.01.021

King, A. J., He, W., Cuevas, J. A., Freudenberger, M., Ramiaramanana, D., \& Graham, I. A. (2009). Potential of Jatropha curcas as a source of renewable oil and animal feed. Journal Experimental of Botany, 60(10), 2897-2905. https://doi.org/10.1093/jxb/erp025

King, A. J., Montes, L. R., Clarke, J. G., Itzep, J., Perez, C. A., Jongschaap, R. E., ... Graham, I. (2015). Identification of QTL markers contributing to plant growth, oil yield and fatty acid composition in the oilseed crop Jatropha curcas L. Biotechnology for Biofuels, 8, 1-17. https://doi.org/10.1186/s13068-015-0326-8

Kumar, S., \& Singh, S. (2014). Variability assessment of seed traits in Jatropha curcas L. for improvement of oil yield. International Journal of Genetics and Molecular Biology, 6(1), 8-15. https://doi.org/10.5897/IJGMB2013.0079

Laviola, B. G., Alves, A. A., Gurgel, F. D., Rosado, T. B., Rocha, R. B., \& Albrecht, J. C. (2012). Estimates of genetic parameters for physic nut traits based in the germplasm two years evaluation. Ciência Rural, 42(3), 429-435.

https://doi.org/10.1590/S0103-84782012000300008

Laviola, B. G., Bhering, L. L., Mendonca, S., Rosado, T. B. \& Albrecht, J. C. (2011). Caracterização morfo-agronômica do banco de germoplasma de pinhão manso na fase jovem. Bioscience Journal, 27(3), 371-379.

Laviola, B. G., Silva, D. A. S., Juhász, A. C. P., Rocha, R. B., Oliveira, R. J. P., Albrecht, J. C., ... Rosado, T. B. (2014). Desempenho agronômico e ganho genético pela seleção de pinhão-manso em três regiões do Brasil. Pesquisa Agropecuária Brasileira, 49(5), 356-363. https://doi.org/10.1590/S0100-204X2014000500005 


\section{Al Macrothink}

Journal of Agricultural Studies

ISSN 2166-0379

2020, Vol. 8, No. 3

Liang, C. J., \& Wang, W. M. (2013). Antioxidant response of soybean seedlings to joint stress of lanthanum and acid rain. Environmental Science and Pollution Research, 20(11), 8182-8191. https://doi.org/10.1007/s11356-013-1776-9

Madhusudhan, R., Ishikawa, T., Sawa, Y., Shigeoka, S., \& Shibata, H. (2003). Characterization of an ascorbate peroxidase in plastids of tobacco BY-2 cells. Physiology Plantarum, 17, 550-557. https://doi.org/10.1034/j.1399-3054.2003.00066.x

Maes, W. H., Achten, W. M. J., Reubens, B., Raes, D., Samson, R., \& Muys, B. (2009). Plant-water relationships and growth strategies of Jatropha curcas L. seedlings under different levels of drought stress. Journal of Arid Environmets, 73, 877-884. https://doi.org/10.1016/j.jaridenv.2009.04.013

Mastan, S., Sudheer, P., Rahman, H., Ghosh, A., Rathore, M., Ravi Prakash, C., \& Chikara, J. (2012). Molecular characterization of intra-population variability of Jatropha curcas L. using DNA based molecular markers. Molecular Biology Reports, 39(4), 4383-4390. https://doi.org/10.1007/s11033-011-1226-z

Matos, F. S., Oliveria, L. R., Freitas, R. G., Evaristo, A. B., Missio, R. F., \& Cano, M. A. O. (2012). Physiological characterization of leaf senescence of Jatropha curcas L. populations. Biomass and Bioenergy, 45, 57-64. https://doi.org/10.1016/j.biombioe.2012.05.012

McCready, R. M., Guggolz, J., Silveira, V., \& Owens, H. S. (1950). Determination of starch and amylose in vegetables. Application to peas. Analytical Chemistry, 22(9), 1156-1158. https://doi.org/10.1021/ac60045a016

Medina, I. O., Sanchez-Gutierrez, A., Adrano-Anaya, L., Espinosa-Gracia, F., Núnez-Farfan, J., \& Salvador-Figureueiroa, M. (2011). Genetic diversity in Jatropha curcas populations in State of Chiapas, Mexico. Diversity, 3(4), 641-659. https://doi.org/10.3390/d3040641

Montes Osorio, L. R., Torres Salvador, A. F., Jongschaap, R. E. E., Azurdia Perez, C. A., Sandoval, J. E. B., Trindade, L. M., ... van Loo, E. N. (2014). High level of molecular and phenotypic biodiversity in Jatropha curcas from Central America compared to Africa, Asia and South America. BMC Plant Biology, 14, 77.

Oliveira, P. S., Silva, L. D., Santana, T. A., Laviola, B. G., Paiva, A. Q., Mielke, M. S., \& Gomes, F. P. (2016). Morphophysiological changes in young plants of Jatropha curcas L. (Euphorbiaceae) subjected to water stress and recovery. African Journal of Agricultural Research, 11(45), 4692-4703. https://doi.org/10.5897/AJAR2016.11435

Pazeto, M. S. R., Unêda-Trevisoli, S. H., Corrêa, A. A. P., Vianna, V. F., Leite, D. C., \& Di Mauro, A. O. (2015). Genetic diversity in Jatropha species from different regions of Brazil based on morphological characters and inters-simple sequence repeat (ISSR) molecular markers. African Journal of Biotechnology, 14(25), 2066-2079. https://doi.org/10.5897/AJB2014.14368

Pecina-Quintero, V., Anaya-Lopez, J. L., Zamarripa-Colmenero, A., \& Nunez-Colin, C. A. (2014). Genetic structure of Jatropha curcas L. in Mexico and probable center of origin. Biomass and Bioenergy, 60, 147-155. https://doi.org/10.1016/j.biombioe.2013.11.005 
Pimentel, D., \& Burgess, M. (2014). Biofuel production using food. Environment, Development and Sustainability, 16, 1-3. https://doi.org/10.1007/s10668-013-9505-6

Pirovani, C. P., Carvalho, H. A. S., Machado, R. C. R., Gomes, D. S., Alvim, F. C., Pomella, A. W. V., ... Cascardo, J. C. M., Pereira, G. A. G., Micheli, F. (2008). Protein extraction for proteome analysis from cacao leaves and meristems, organs infected by Moniliophthora perniciosa, the causal agent of the witches' broom disease. Electrophoresis, 29(11), 2391-2401. https://doi:10.1002/elps.200700743

Pompelli, M. F., Antunes, W. C., Ferreira, D. T. R. G., Cavalcante, P. P. G. S., Wanderley-Filho, H. C. L., \& Endres, L. (2012). Allometric models for non-destructive leaf area estimation of the Jatropha curcas L. Biomass and Bioenerg, 36, 77-85. https://doi.org/10.1016/j.biombioe.2011.10.010

Pompelli, M. F., Orozco, A. J. J., Oliveira, M. T., Rodrigues, B. R. M., Barbosa, M. O., Santos, M. G., ... Cortez, J. S. A. (2011). Crise energética mundial e o papel do Brasil na problemática de biocombustíveis. Agronomia Colombiana, 29(2), 231-240.

Prado, A., Mota, F., Pimentel Correa, A., Di Mauro, O., \& Uneda-Trevisoli, S. (2017). Phenotypic diversity in physic nut (Jatropha curcas L.) in vivo germplasm bank for superior parent selection. African Journal of Biotechnology, 16(17), 953-996. https://doi.org/10.5897/AJB2017.15890

Rao, G. R., Korwar, G. R., Shanker, A. K., \& Ramakrishna, Y. S. (2008). Genetic associations, variability and diversity in seed characters, growth, reproductive phenology and yield in $\begin{array}{lllll}\text { Jatropha curcas (L.) accessions. } & \text { Trees, } & \text { 22(5), }\end{array}$ https://doi.org/10.1007/s00468-008-0229-4

Ren, X. Q., Zhu, J. Z., Liu, H. Y., Xu, X., \& Liang, C. J. (2018). Response of antioxidative system in rice (Oryza sativa) leaves to simulated acid rain stress. Ecotoxicology and Environmental Safety, 148, 851-856. https://doi.org/10.1016/j.ecoenv.2017.11.046

Rencher, A. C. (2002). Methods of Multivariate Analysis. A John Wiley \& Sons, Inc. Publication p.727. 2ed. 2002.

Ricci, A., Chekhovskiy, K., Azhaguvel, P., Albertini, E., Falcinelli, M., \& Saha, M. (2012). Molecular characterization of Jatropha curcas resources and identification of population-specific markers. Bioenergy Research, 5, 215-224. https://doi.org/10.1007/s12155-011-9150-6

Rocha, R. B., Ramalho, A. R., Teixeira, A. L., Laviola, B. G., Silva, F. C. G., \& Militão, J. S. L. T. (2012). Eficiência da seleção para incremento do teor de óleo do pinhão-manso. Pesquisa Agropecuária Brasileira, 41(1), 44-50.

Rosado, T. B., Laviola, B. G., Faria, D. A., Pappas, M. R., Bhering, L. L., Quirino, B., \& Grattapaglia, D. (2010). Molecular markers reveal limited genetic diversity in a large germplasm collection of the biofuel crop Jatropha curcas L. in Brazil. Crop Science, 50, 2372-2382. https://doi.org/10.2135/cropsci2010.02.0112 
Santana, T. A., Oliveira, P. S., Silva, L. D., Laviola, B. G., Almeida, A-A.F., \& Gomes, F. P. (2015). Water use efficiency and consumption in different Brazilian genotypes of Jatropha curcas L. subjected to soil water deficit. Biomass and Bioenergy, 75, 119-125. https://doi.org/10.1016/j.biombioe.2015.02.008

Santana, T. A., Silva, L. D., Oliveira, P. S., Benjamin, C. S., Ramos, E. P., Souza Júnior, J. O., \& Gomes, F. P. (2017). Leaf gas exchange and biomass partitioning in Jatropha curcas L. young plants subjected to flooding and drought stresses. Australian Journal of Crop Science, 11(7), 792-798. https://doi.org/10.21475/ajcs.17.11.07.pne354

Santos, C. A. F., Drumond, M. A., Rodrigues, M. A., Evangelista, M. R. A. (2010). Genetics similarity of Jatropha curcas accessions based on AFLP markers. Crop Breeding and Applied Biotechnology, 10(4), 364-369. https://doi.org/10.1590/S1984-70332010000400012

Shabanimofrad, M., Rafii, M. Y., Wahab, P. E. M., Biabani, A. R., \& Latif, M. A. (2013). Phenotypic, genotypic and genetic divergence found in 48 newly collected Malaysian accessions of Jatropha curcas L. Industrial Crops and Products, 42, 543-551. https://doi.org/10.1016/j.indcrop.2012.06.023

Shen, J., Jia, X., Ni, H., Sun, P., Niu, S., \& Chen, X. (2010). AFLP analysis of genetic diversity of Jatropha curcas grown in Hainan. Trees, 24(3), 455-462. https://doi.org/10.1007/s00468-010-0413-1

Shu, X., Yin, L. Y., Zhang, Q. F., \& Wang, W. B. (2012). Effect of Pb toxicity on leaf growth, antioxidant enzyme activities, and photosynthesis in cuttings and seedlings of Jatropha curcas L. Environmental Science and Pollution Research, 19(3), 893-902. https://doi.org/10.1007/s11356-011-0625-y

Silva, L. D., Gomes, F. P., Oliveira, P. S., Almeida, F. R., Pirovani, C. P., Laviola, B. G., \& Amaral, J. F. T. (2019). Plasticity of photosynthetic metabolism in Jatropha curcas genotypes under water deficit. Genetics and Molecular Research, 18(2), 1-17. https://doi.org/10.4238/gmr18228

Silva, L. D., Santana, T. A., Oliveira, P. S., Laviola, B. G., Costa, M. G. C., Almeida, A-A.F., \& Gomes, F. P. (2016). Abscisic acid-mediated stomatal closure and antioxidant defenses in Jatropha curcas L. seedlings submitted to moderate water déficit. African Journal of Agricultural Research, 11(30), 2806-2816. https://doi.org/10.5897/AJAR2015.10587

Singh, D. (1981). The relative importance of characters affecting genetic divergence. Indian Journal of Genetics and Plant Breeding, 41(2), 237-245.

Singh, R., Pandey, R. M., \& Singh, B. (2013). Genetic association, divergence and variability studies for seed yield and oil content and its contributing traits in Jatropha (Jatropha curcas L.). Journal of Medicinal Plants Research, 7, 1931-1939. https://doi.org/10.5897/JMPR12.1285

Sneath, P. H., \& Sokal, R. R. (1973). Numerical taxonomy: The principles and practice of numerical classification. San Francisco: W.H. Freeman, 573p. 


\section{Macrothink Institute}

Srivastava, P., Behera, S. K., Gupta, J., Jamil, S., Singh, N., \& Sharma, Y. K. (2011). Growth performance, variability in yield traits and oil content of selected accessions of Jatropha curcas L. growing in a large scale plantation site. Biomass and Bioenergy, 35, 3936-3942. https://doi.org/10.1016/j.biombioe.2011.06.008

Sunil, N., Vanaja, M., Kumar, V., Abraham, B., \& Chakrabarty, S. (2013). Variation in physiological traits in Jatropha germplasm from peninsular India. Indian Journal of Plant Physiology, 18(2), 151-156. https://doi.org/10.1007/s40502-013-0026-y

Tatikonda, L., Wani, S. P., Kannan, S., Beerelli, N., Sreedevi, T. K., Hoisington, D. A., ... Varshney, R. K. (2009). AFLP-based molecular characterization of an elite germplasm collection of Jatropha curcas L., a biofuel plant. Plant Science, 176(4), 505-513. https://doi.org/10.1016/j.plantsci.2009.01.006

Tripathi, A., Mishra, D. K., \& Shukla, J. K. (2013). Genetic variability, heritability and genetic advance of growth and yield componentes of Jatropha (Jatropha curcas Linn.) genotypes. Trees, 27, 1049-1060. https://doi.org/10.1007/s00468-013-0856-2

Tripathi, A., Mishra, D. K., \& Shukla, J. K. (2015). Genetic diversity and trait association between growth, yield and seed component of Jatropha curcas (L.) source collection from Indian sub-continent. Journal of Plant Breeding and Crop Science, 7(5), 143-157. https://doi.org/10.5897/JPBCS2014.0460

Wani, T. A., Kitchlu, S., \& Ram, G. (2012). Genetic variability studies for morphological and qualitative attributes among Jatropha curcas L. accessions grown under subtropical conditions of North India. South African Journal of Botany, 79, 102-105. https://doi.org/10.1016/j.sajb.2011.10.009

Wilson, J. R., Fisher, M. J., Schulze, E. D., Dolby, G. R., \& Ludlow, M. M. (1979). Comparison between pressure-volume and dew point-hygrometry techniques for determining the water relations characteristics of grass and legume leaves. Oecologia, 41, 77-88. http://doi.org/10.1007/BF00344838

Yin, C. Y., Pang, X. Y., Peuke, A. D., Wang, X., Chen, K., \& Gong, R. G. (2016). Growth and photosynthetic responses in Jatropha curcas L. seedlings of different provenances to watering regimes. Photosythetica, 367-373. https://doi.org/10.1007/s11099-016-0201-2

\section{Copyright Disclaimer}

Copyright for this article is retained by the author(s), with first publication rights granted to the journal.

This is an open-access article distributed under the terms and conditions of the Creative Commons Attribution license (http://creativecommons.org/licenses/by/4.0/). 